\title{
Financial mechanisms to stimulate the real economy in the global economic security system
}

\author{
Pavel Klimenko ${ }^{1, *}$, Larisa Sevryukova ${ }^{1}$, Mikhail Goncharenko ${ }^{2}$, and Dmitry Dmitriev ${ }^{l}$ \\ ${ }^{1}$ Southwest State University, Faculty of Economics and Manaqement, Department of Economic \\ Security and Taxation, Kursk, 50 Let Oktyabrya Street, 94, Russia \\ ${ }^{2}$ Financial University, Faculty of Finance and Economics (GUMF). Department of Banking and \\ Financial Markets, Moscow, Leningradsky Ave., 49 \\ ${ }^{4}$ Southwest State University, Faculty of Economics and Manaqement, Department of Economic \\ Security and Taxation, Kursk, 50 Let Oktyabrya Street, 94, Russia
}

\begin{abstract}
.
Research background: The real sector plays a crucial role in the country's economy. It is he who serves as the economic basis for creating an additional product, in close connection with the financial sector. Today, the concept of "real sector of the economy" is used very actively both in economic science and in economic practice. Favourable macroeconomic factors lead to investment in the real sector and increase the competitiveness of production, both the economy of the individual state and the global economy as a whole. Research aimed at improving the efficiency of the real sector through the development of financial mechanisms to support it on a global scale is therefore highly relevant to the economic security of individual countries and the world economy.

Purpose of the article: identification of current problems and ways of improvement, financial mechanisms to stimulate the real sector of the economy to ensure economic security of the state

Methods: spatio-temporal analysis of the identified indicators of balanced development of the regional economy in order to ensure economic security.

Findings \& Value added: Findings \& Value added: proposed ways to develop effective financial mechanisms to stimulate the real sector of the economy can be used in the development of economic security strategies for regions and federal districts
\end{abstract}

Keywords: real sector of economy; industrial policy; gross regional product; tax incentives

JEL Classification: $O 32 ; O 49$

*Corresponding author: pklimenko.81@mail.ru 


\section{Introduction}

The real sector plays a crucial role in the country's economy. It is the economic basis for creating a surplus product that ensures the functioning of the financial sector. Favorable macroeconomic factors ensure the inflow of investment in the real sector and increase the competitiveness of production. In this regard, research aimed at solving problems to improve the efficiency of the real sector of the economy is extremely relevant for ensuring the economic security of the state. Any changes in economic sectors affect the national level of a state and affect the global economic system.

Currently, in the sphere of state regulation and creation of mechanisms to support the real sector of the economy, a "turn" is being made from active direct intervention in the activities of economic entities to creating an environment that promotes entrepreneurial activity, innovation, fair competition and orientation to the development of new markets.

In this regard, the set of state support tools should change. It is necessary to support demand, develop the institutional environment, and build a system of long-term, sustainable and predictable measures aimed at "forcing" enterprises to improve efficiency, including equalizing macroeconomic indicators both at the national level and on a global scale.

The existing mechanisms of state stimulation of the real sector of the economy are based on two main directions: industrial and structural.

However, as world practice shows, in the real sector of the Russian economy, we can allocate much more tools for stimulating and implementing state support for priority sectors of the economy. The more tools we can use to help the real sector of the economy, the faster it will develop.

\section{2 Literature review}

Today, in the formation of effective methods and mechanisms for stimulating the real sector of the economy, both at the national and international levels, it is necessary to activate financial instruments aimed at creating additional opportunities for the development of priority sectors of the real sector of the economy, at encouraging innovation and creating a favorable investment climate in globally.

The approach [1] is of interest, as it allows to form the necessary tools for innovative stimulation of investment processes in the real sector of the economy.

The authors $[2,3]$ describe the methods and mechanisms of state financial regulation based on the creation of optimal conditions for the development of promising sectors of the economy, taking into account the optimization of state fiscal policy and the introduction of program budgeting tools.

The assessment of the influence of favorable and unfavorable factors of the world economy on the development of the real sector of the economy at the regional level is reflected in the works $[4,6]$. Such an analysis makes it possible for regional authorities to form concepts for the development of regions, taking into account world trends and the characteristics of the modern global economy.

In the applied aspect, the results of works [7, 8] are interesting, where there is an attempt to form indicators and indicators of economic security in the budgetary sphere, as well as substantiation of the possibility of their use in the real economy.

When reviewing the literature, it should be noted that an important direction in the development of the modern economy and its real sector is its impact on social processes, which is reflected in the works [9, 11]. The authors of these works propose for consideration indicators of a comprehensive assessment of economic security, including economic, social and blocks. 
Despite the instruments of innovation and investment incentives described in the studies under consideration, methods of optimizing the state's fiscal policy, indicators of economic security, there is a need to generalize the already accumulated experience. In addition, there is an urgent need to adapt international experience in the implementation of programs to stimulate the real sector of the economy and create conditions for the formation of economic security at various levels of management.

\section{Results}

The features and main trends of the Russian industrial policy and directions of development of the industrial sector in recent years are determined by the state of the national economy and the influence of the state's foreign policy and its position in the world economy. This is due to the impact on the development of the Russian economic system of anti-Russian sanctions and the collapse of the national currency, which led to numerous financial difficulties and problems

Analyzing the economic system of any country, it is advisable to distinguish two interrelated, but working separately sectors: financial and real.

The real sector of any country is characterized by features that depend on the current level of economic development (developed and developing) and the structure of the economy with industry leaders. The type of economic system influences the formation and subsequent development of the proportions of the real sector. This factor is crucial when identifying the characteristics of the real sector. As in other countries of the world, in Russia the real sector is the basis of the national economy, which determines its level and specialization. It employs the population and produces about the same part of GDP. The real sector of the economy is represented by a wide range of industries. The specifics of the real sector of the Russian economy is its priority in the field of industries related to the extraction of raw materials and fuel, as well as the production of energy and materials. On the one hand, this is a consequence of the use of natural resources in the national economy, primarily mineral resources. This situation allows Russia to remain a competitive country and use this competitive advantage.

For consideration, we will take data on the following industries: electric power, agriculture, and construction.

The rationalization of the industry structure of industrial production is associated with agriculture and construction. Economic, geographical and demographic factors make it possible to form an agro-industrial complex within the regional system. The creation of interconnected industries in the region will increase food and economic security of the region and socio-economic development level of agricultural districts.

The analysis of the state of the real sector of the Russian economy in the selected sectors of economic activity for 2014-2018 was carried out, using official information provided by the Federal state statistics service and the Federal tax service of the Russian Federation, the data are presented in Table 1. 
Table 1. Dynamics of changes in the main indicators that characterize the effectiveness of industrial policy in the Russian Federation by type of economic activity for 2015-2018, billion rubles (A1).

\begin{tabular}{|c|c|c|c|c|c|c|c|c|}
\hline \multirow[t]{3}{*}{ № } & \multirow{3}{*}{$\begin{array}{l}\stackrel{D}{E} \\
\stackrel{0}{E} \\
\stackrel{\Xi}{E}\end{array}$} & \multirow[t]{3}{*}{ Indicator } & \multicolumn{6}{|c|}{ Deviation } \\
\hline & & & \multicolumn{2}{|c|}{$2016 / 2015$} & \multicolumn{2}{|c|}{$2017 / 2016$} & \multicolumn{2}{|c|}{ 2018/2017 } \\
\hline & & & $\begin{array}{l}\text { Absolute } \\
\text { deviation }\end{array}$ & $\begin{array}{c}\text { Growth } \\
\text { rate }\end{array}$ & $\begin{array}{l}\text { Absolute } \\
\text { deviation }\end{array}$ & $\begin{array}{c}\text { Growth } \\
\text { rate }\end{array}$ & $\begin{array}{l}\text { Absolute } \\
\text { deviation }\end{array}$ & $\begin{array}{c}\text { Growth } \\
\text { rate }\end{array}$ \\
\hline \multirow[t]{5}{*}{2} & \multirow{5}{*}{ 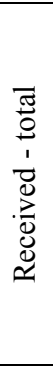 } & $\begin{array}{l}\text { Gross added } \\
\text { value }\end{array}$ & 2456,6 & 103,3 & 5820,2 & 107,6 & 10989 & 113,3 \\
\hline & & Investment & 851,6 & 106,1 & 1278,5 & 108,7 & 1567,7 & 109,8 \\
\hline & & $\begin{array}{ll}\text { Number } \\
\text { personnel }\end{array}$ & 3676,1 & 105,4 & $-222,5$ & 99,7 & $-116,4$ & 99,8 \\
\hline & & Value of assets & 11039 & 106,6 & 22885 & 113,3 & 11838 & 106,1 \\
\hline & & $\begin{array}{l}\text { Corporate } \\
\text { income tax }\end{array}$ & 235,7 & 109,7 & 561,5 & 120,9 & 764,3 & 123,6 \\
\hline \multirow[t]{5}{*}{3} & \multirow{5}{*}{ 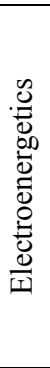 } & $\begin{array}{l}\text { Gross added } \\
\text { value }\end{array}$ & 181,4 & 108,7 & 145,2 & 106,4 & 79,1 & 103,3 \\
\hline & & Investment & $-51,9$ & 94,3 & 77,7 & 108,9 & 103,8 & 110,9 \\
\hline & & $\begin{array}{l}\text { Number } \\
\text { personnel }\end{array}$ & 68 & 103,5 & $-358,8$ & 81,9 & $-24,6$ & 98,5 \\
\hline & & Value of assets & 879 & 106,8 & -102 & 99,3 & 1045 & 107,6 \\
\hline & & $\begin{array}{l}\text { Corporate } \\
\text { income tax }\end{array}$ & 25,4 & 147,7 & 55,2 & 170,2 & $-11,3$ & 91,5 \\
\hline \multirow[t]{5}{*}{4} & \multirow{5}{*}{ 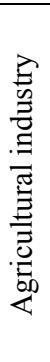 } & $\begin{array}{l}\text { Gross added } \\
\text { value }\end{array}$ & 69,7 & 102,2 & -24 & 99,3 & 264,8 & 108,1 \\
\hline & & Investment & 104,6 & 120,2 & 82,1 & 113,2 & 71,5 & 110,1 \\
\hline & & $\begin{array}{l}\text { Number } \\
\text { personnel }\end{array}$ & -919 & 85,4 & -299 & 94,4 & -98 & 98,1 \\
\hline & & Value of assets & 485 & 111,3 & 1022 & 121,4 & 534 & 109,2 \\
\hline & & $\begin{array}{l}\text { Corporate } \\
\text { income tax }\end{array}$ & 0,6 & 107,3 & 5,1 & 157,9 & 2,9 & 120,9 \\
\hline \multirow[t]{5}{*}{5} & \multirow{5}{*}{ 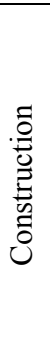 } & $\begin{array}{l}\text { Gross added } \\
\text { value }\end{array}$ & 177,3 & 103,8 & 98,8 & 102,0 & 343 & 106,9 \\
\hline & & Investment & 42,5 & 110,6 & 67,8 & 115,3 & 124,7 & 124,4 \\
\hline & & $\begin{array}{l}\text { Number } \\
\text { personnel }\end{array}$ & 579,3 & 110,2 & 87,8 & 101,4 & $-9,5$ & 99,8 \\
\hline & & Value of assets & 185 & 109,0 & -43 & 98,1 & 199 & 109,1 \\
\hline & & $\begin{array}{l}\text { Corporate } \\
\text { income tax }\end{array}$ & 7,5 & 106,8 & 3,9 & 103,3 & 3,9 & 103,2 \\
\hline
\end{tabular}

Source: compiled by the author on the basis of EMISS statistics for 2014-2018; statistical collections «Russia in numbers 2015-2019».

Since tax credits and incentives represent lost tax state income or resources that could be used in other forms of public support, to assess the effectiveness of their application, it is primarily necessary to compare the amount of spending on tax benefits and incentives with 
the results obtained from tax breaks and incentives at the firm level, the state and society as a whole.

Therefore, we consider it important to analyze the receipts of corporate income tax to the Federal budget (table 2).

Table 2. Dynamics of changes in corporate income tax receipts in the Russian Federation by type of economic activity for 2014-2018, billion rubles (A2).

\begin{tabular}{|c|c|c|c|c|c|c|c|c|}
\hline \multirow{2}{*}{$\begin{array}{c}\text { Corporate } \\
\text { income tax }\end{array}$} & \multicolumn{2}{|c|}{2015} & \multicolumn{2}{c|}{2016} & \multicolumn{2}{c|}{2017} & \multicolumn{2}{c|}{2018} \\
\cline { 2 - 9 } & $\begin{array}{c}\text { Billion } \\
\text { rubles }\end{array}$ & $\begin{array}{c}\text { Specific } \\
\text { weight }\end{array}$ & $\begin{array}{c}\text { Billion } \\
\text { rubles }\end{array}$ & $\begin{array}{c}\text { Specific } \\
\text { weight }\end{array}$ & $\begin{array}{c}\text { Billion } \\
\text { rubles }\end{array}$ & $\begin{array}{c}\text { Specific } \\
\text { weight }\end{array}$ & $\begin{array}{c}\text { Billion } \\
\text { rubles }\end{array}$ & $\begin{array}{c}\text { Specific } \\
\text { weight }\end{array}$ \\
\hline $\begin{array}{c}\text { Received - } \\
\text { total }\end{array}$ & 2442,2 & 100 & 2677,9 & 100 & 3239,4 & 100 & 4003,7 & 100 \\
\hline $\begin{array}{c}\text { Electro- } \\
\text { energetics }\end{array}$ & 53,2 & 2,2 & 78,6 & 2,9 & 133,8 & 4,1 & 122,5 & 3,1 \\
\hline $\begin{array}{c}\text { Agricultural } \\
\text { industry }\end{array}$ & 8,2 & 0,3 & 8,8 & 0,3 & 13,9 & 0,4 & 16,8 & 0,4 \\
\hline Construction & 110,3 & 4,5 & 117,8 & 4,4 & 121,7 & 3,8 & 125,6 & 3,1 \\
\hline
\end{tabular}

Source: compiled by the author on the basis of reports of the Federal tax service 1-NOM.

After analyzing the tax reports on Federal tax service 1-NOM, were able to make the following data:

First, the level of corporate income tax revenues in the Russian Federation as a whole increased by $75 \%$ in 2018 compared to 2015 . This can tell us about several factors: an increase in the tax burden on organizations, the fact that the number of enterprises in the real economy has increased, or the effective work to identify and solve economic tax crimes.

A sharp jump in corporate income tax revenue occurred in 2017 in the electric power industry, revenue exceeded 2016 by 55 billion rubles, that is, by $70 \%$, but by 2018 it decreased by $9 \%$.

In agriculture, as well as in the electric power industry, there was a jump in 2017 and the volume of corporate income tax receipts increased by $58 \%$, then by another $21 \%$ in 2018.

The General idea of evaluating the effectiveness of tax incentives and incentives is to compare the amount of expenditures and the results they generate, i.e., additional revenue for firms, the state, and society as a whole.

It is important to understand that in order to correctly allocate resources between various types of industrial policy activities in order to optimize costs, it is necessary to have information about which types of activities are branches of specialization in the territory under consideration and where the tax benefits offered by the state can bring the greatest benefit to the country's economic security by increasing the productivity of the real sector of the Russian Federation's economy.

As practice shows, the Quantitative analysis of earlier decisions taken by the state in the field of granting tax benefits and preferences is not systematically performed. However, there are some individual evaluation by independent bodies of financial control (accounts chamber of the Russian Federation), the Ministry of Finance of Russia and FTS of Russia. Thus, in 2018, the accounts chamber of the Russian Federation conducted a review of the validity of the provision and use of corporate income tax benefits and an analysis of their relevance in order to stimulate innovation, and estimated the loss of revenues of the consolidated budget of the Russian Federation from the application of 128 corporate income tax benefits and preferences in the period from 2015 to the first half of 2017 in the amount of 1,027.1 billion rubles. 
In 2019, the accounts chamber of Russia held a broader expert and analytical event "assessment of the effectiveness of providing tax benefits and preferences and their stimulating impact on the efficiency of the economy", which resulted in an annual increase in the amount of lost revenues of the consolidated budget of the Russian Federation: from 4.16 trillion rubles in 2016 to 6.75 trillion rubles in 2017.

As a result of the examination, it was concluded that out of 359 tax benefits and preferences at the beginning of 2018, 152 have an impact on the economy, and 142 have a social orientation. It should be noted that the accounting chamber estimates that 80 to $90 \%$ of the specified amounts of lost income are lost income from value-added tax benefits.

The Russian accounting chamber's assessment of budget tax expenditures by type of tax is shown in table 3 below.

Table 3. Evaluation of the Ministry of Finance's tax expenditures of budgets of the budgetary system of the Russian Federation in 2015-2019 by types of taxes (A3).

\begin{tabular}{|c|c|c|c|c|c|c|}
\hline \multirow{2}{*}{ № } & Type of taxes & \multicolumn{5}{|c|}{ Period } \\
\cline { 2 - 6 } & $\mathbf{2 0 1 5}$ & $\mathbf{2 0 1 6}$ & $\mathbf{2 0 1 7}$ & $\mathbf{2 0 1 8}$ & $\mathbf{2 0 1 9}$ \\
\hline 1 & $\begin{array}{c}\text { Corporate income tax, billion } \\
\text { rubles }\end{array}$ & 207 & 213 & 212 & 228 & 251 \\
\hline 2 & $\begin{array}{c}\text { VAT and import duty, billion } \\
\text { rubles }\end{array}$ & 1071 & 1094 & 1208 & 1289 & 1356 \\
\hline 3 & Severance tax revenue. & 364 & 353 & 412 & 393 & 457 \\
\hline 4 & Export duties, billion rubles & 154 & 90 & 134 & 144 & 145 \\
\hline 5 & Total, billion rubles & 2163 & 2209 & 2449 & 2521 & 2598 \\
\hline 6 & Percentage of GDP, in \% & 2,6 & 2,6 & 2,5 & 2,5 & 2,4 \\
\hline
\end{tabular}

Source: compiled by the author on the basis of reports of the Federal tax service 1-NOM.

There is also a third assessment of tax expenditures for 2015-2019 based on the results of the inventory of tax benefits by the Ministry of Finance of the Russian Federation, conducted in February 2020.

As you can see, agencies have different assessments of the role of corporate income tax, VAT, and corporate property tax benefits in the loss of state fiscal revenues. Such differences demonstrate the problem of determining tax benefits for the purpose of estimating the corresponding tax expenditures. The Russian Ministry of Finance has not conducted an analysis of tax expenditures in the context of OKVED industries, but based on the classification in the context of state programs, the upper limit of the volume of tax incentives directly or indirectly related to industrial enterprises can be estimated in 2019 at 763 billion rubles, or $0.9 \%$ of GDP. The Ministry of Finance of the Russian Federation estimates the tax expenditures of the budgets of the budget system of the Russian Federation by type of taxes are shown in table 4.

Analysis of the data presented in table 4 showed that, despite the fact that the generalized indicator of tax expenditures in industry of 763 billion rubles is 4.5 times higher than our estimate of subsidies of 170 billion rubles. Based on a detailed study of the structure of tax expenditures, it should be concluded that in $201672 \%$, and in $2019-88 \%$ of tax expenditures relate to the program «Reproduction and use of natural resources», that is, they are related to met and export duties. Without taking into account these taxes and fees on rental income, we can talk about the comparability of the volume of industrial production incentives through budget subsidies and tax incentives. According to the Federal 
Treasury on the implementation of the consolidated budget of the Russian Federation and the budgets of state extra - budgetary funds for 2016, the volume of subsidies to legal entities (except non - profit organizations), individual entrepreneurs, and individuals who produce goods, works, and services amounted to 1370.0 billion rubles, or $4.4 \%$ of all budget expenditures and $1.6 \%$ of GDP, of which 548.2 billion rubles came from the Federal budget, as well as the volume of subsidies to state corporations -379.2 billion rubles.

Table 4. Assessment of the Ministry of Finance of the Russian Federation of tax expenditures of budgets of the budgetary system in 2014-2019 in terms of state programs related to the development of industry (A4).

\begin{tabular}{|c|c|c|c|c|c|c|}
\hline \multirow{2}{*}{ № } & \multirow{5}{*}{ Name of the support program } & \multicolumn{5}{|c|}{ Period } \\
\cline { 3 - 7 } & $\begin{array}{c}\text { De15 } \\
1\end{array}$ & $\mathbf{2 0 1 6}$ & $\mathbf{2 0 1 7}$ & $\mathbf{2 0 1 8}$ & $\mathbf{2 0 1 9}$ \\
\hline 2 & $\begin{array}{c}\text { Development of industry and } \\
\text { increasing its competitiveness, } \\
\text { billion rubles }\end{array}$ & 42 & 43 & 44 & 47 & 51 \\
\hline 4 & $\begin{array}{c}\text { Reproduction and use of natural } \\
\text { resources, billion rubles } \\
\text { development, billion rubles }\end{array}$ & 566 & 550 & 684 & 669 & 744 \\
\hline 5 & $\begin{array}{c}\text { Development of science and } \\
\text { technology for 2013-2020, billion } \\
\text { rubles }\end{array}$ & 59 & 87 & 91 & 95 & 36 \\
\hline 6 & Total, billion rubles & 769 & 763 & 884 & 854 & 843 \\
\hline 7 & Percentage of GDP, \% & 0,92 & 0,89 & 0,86 & 0,85 & 0,83 \\
\hline
\end{tabular}

Source: compiled by the author on the basis of EMISS statistics for 2014-2018; statistical collections «Russia in numbers 2015-2019».

Data on subsidies to industrial entities are not provided, but based on the law «On the Federal budget for 2018», the corresponding Federal budget allocations can be estimated at 170 billion rubles, of which 135 billion rubles are planned for industry subsidies.

Therefore, we consider it important to monitor the implementation of the tax benefits provided to increase the productivity of the enterprise.

To control the implementation of the program to exempt organizations from paying corporate income tax, we also propose to introduce an electronic control system, which will be carried out by submitting a tax return with a report on the accrued corporate income tax and redistributed for the purpose of improving production efficiency.

\section{Discussion and conclusion}

Thus, according to the results of the study, it can be concluded that when forming financial mechanisms for stimulating the real sector of the economy, both within the national and global systems, it is necessary to:

- meeting the demand of the population of the region and the state as a whole for goods and services to the extent possible to ensure economic growth and economic security of the state;

- providing conditions for the development of the regional economic complex;

- formation of a rational industry structure of industrial production;

- ensuring the location and development of industrial production in the region; 
- creating a rational structure for managing regional production in order to ensure the economic security of the state;

- providing conditions for increasing the possible level of production in the region for different industries;

- ensuring the development of the region's production forces capable of satisfying the economic complex in goods, works and services;

- creating a favorable financial and tax climate for entrepreneurs;

Many programs for the development of Russia and its regions until 2025 identify priority sectors for investment and tax incentives such as: agriculture; manufacturing, primarily food and processing industries; mining; and electric power. Our analysis shows the real need to stimulate these sectors of the economy.

In turn, we propose a sequence of priorities that allows us to create a synergistic effect aimed at creating conditions for advanced development of the real sector of the Russian economy. Our proposed sequence of priorities for the development of the real sector of the Russian economy is shown in Fig. 1

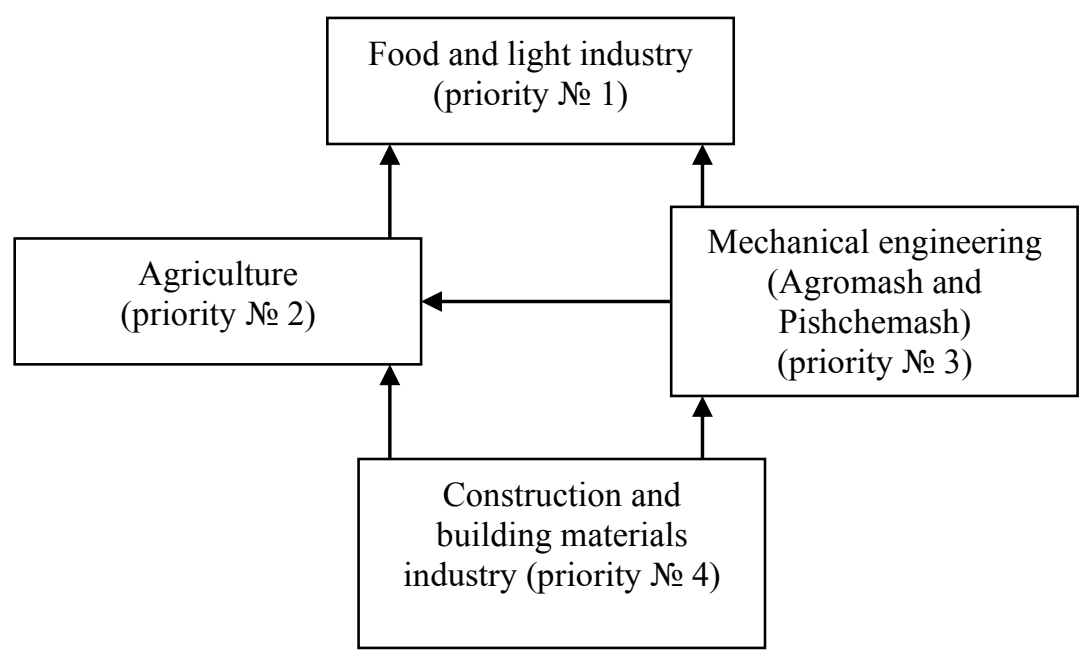

Fig. 1. Priorities for the development of branches of the real sector of the Russian economy.

The development of the real sector of the Russian economy is largely associated with the development of agriculture and processing industries. In this regard, the proposed sequence in the formation of priorities for the development of branches of the real sector of the Russian economy will ensure high growth rates of economic and financial indicators and create conditions for ensuring the economic security of the state.

\section{References}

1. Pogodina T. V., Aleksakhina V. G., Burenin V. A., Polianova T. N., Yunusov L. A. (2019). Towards the innovation-focused industry development in a climate of digitalization: the case of Russia. Entrepreneurship and Sustainability Issues, 6(4), 1897-1906.

2. Trusova N., Klimenko P., Prikhodchenko O. (2015). Regional State Fiscal Policy: Russian and Foreign Experience. Mediterranean Journal of Social Sciences, 6(6), 436-443 
3. Trusova N., Klimenko P., Prikhodchenko O., Plotnikov V. (2015). Program budgeting as a mechanism to achieve social and economic development of the region. Proceedings of the $2^{\text {nd }}$ International multidisciplinary scientific conference of social sciences and arts - SGEM Conference proceedings. Book 2: Political sciences, law, finance, economics and tourism. Volume II: Finance, economics and tourism (pp. 851858). Albena, Bulgaria: SGEM.

4. Sevriukova L. V., Trusova N. C. (2014). State policy to promote investment activity in regions. Economic Annals, XXI(9-10), 106-107.

5. Tsiklauri V. Y., Devyatilova A. I., Artemov R. V., Markina S. A. (2017). Shadow globalization as a threat to world economic growth. In K. S. Soliman (Ed.), Education Excellence and Innovation Management through Vision 2020 From Regional Development Sustainability to Global Economic Growth: Proceedings of the 29th International Business Information Management Association Conference (pp. 2478-2489). Vienna, Austria: IBIMA.

6. Klimenko P., Markina S., Mashkina N. (2017). The influence of processes of financial globalization and transformation on the word financial and credit system. In Proceedings of the $4^{h}$ SGEM International Multidisciplinary Scientific Conference on Social sciences and Arts: (pp. 847-852).

7. Tkacheva T. Y., Sevryukova L. V., Afanasyeva L. V. (2016). Organizational and Functional Features of Fiscal Mechanisms: Theoretical Aspects and Current Trends. The Social Sciences, 11(15), 3692-3696.

8. Tkacheva T. Y., Afanasjeva L. V., Sevrukova L. V., Goncharenko L. I., Panskov V. G. (2019). Formation of modern fiscal mechanisms: integrated approach. In K. S. Soliman (Ed.), Education Excellence and Innovation Management through Vision 2020: Proceedings of the 33rd International Business Information Management Association Conference IBIMA 2019 (pp. 9578-9582). Granada, Spain: IBIMA.

9. Trusova N., Klimenko P. (2016). Building of socio-economic politics in the context of regional safety. Економічний часопис, XXI(3-4), 38-40.

10. Kirilchuk I., Rykunova V., Panskov V. (2018). Indicators of sustainable development as indicators of ecological-economic safety. In Proceedings of the 18th International Multidisciplinary Scientific GeoConferences SGEM 2018 (pp. 491-498).

11. Rykunova V., Goncharenko L., Belousova S. (2017). Enhancement of the incentive function of economic mechanism for rational natural resources management. In Proceedings of the 17th International Multidisciplinary Scientific Geoconference SGEM 2017 (pp. 285-292). 